\title{
What do otters eat where there is no fish?
}

\author{
Jacinto Román* \\ Department of Conservation Biology, Estacion Biologica de Doñana (EBD), Consejo Superior de Investigaciones Científicas (CSIC) Avda. Americo Vespucio s/n, 41092 Sevilla, Spain
}

\author{
a b s t r a c t
}

Keywords:

Otter Doñana

Crayfish

Diving beetle

Temporary ponds
Recently, Clavero et al. (2008) found a negative relationship between the stability of water courses and the occurrence of fishes in otter diet. We studied otter diet in a place of mainly temporary water in form of small ponds and streams strongly dependent on rainfall. Our results constitute the extreme of the gradient of water instability, where otters do not prey upon fish but depend on crayfishes and diving beetles to survive.
The Eurasian otter (Lutra lutra) is a semi-aquatic predator specialized in feeding on fishes (Mason and Mcdonald, 1986), which normally constitute the bulk of its diet (Carss, 1995; Clavero et al., 2003). Many papers have described the diet of the European otter based on spraint sampling. These studies indicate that alternative preys like amphibians and crustaceans may form the bulk of the diet, especially in Mediterranean freshwater systems (Beja, 1996; Pedroso and Santos-Reis, 2006; Prigioni et al., 2006; Remonti et al., 2008; Ruiz-Olmo and Jimenez, 2009). Recently, Clavero et al. (2008) found a negative relationship between the stability of water courses and the occurrence of fishes in otter diet. We studied otter diet in a place of mainly temporary water in form of small ponds and streams strongly dependent on rainfall. These ponds are occupied by the otter only occasionally and for relatively short periods of time. These cases provide the opportunity for study the diet of the otter in the extreme of the hydrological stability gradient, where we expected the fish to be rare or absent.

Doñ ana National and Natural Parks are located in south-western Spain, in the right margin of the lower Guadalquivir river (Fig. 1). In this area, the otter has been historically recorded in the few permanent water courses, namely the Rocina stream and their tributaries in the northern border of the Park (Adrián et al., 1990; Barroso and Pineda, 1998). The scarcity of records in the rest of the Park has been related to instability of either streams or ponds (Adrián et al., 1990). We analyzed otter diet in the western part of the Natural Park, an area of weakly cemented white-yellowish sandstone of aeolian origin with few layers rich in clay and organic matter interbedded (Zazo et al., 1999). Rainfall in this area is highly vari-

\footnotetext{
* Corresponding author.

E-mail address: jroman@ebd.csic.es.
}

able, with a range of $170-1000 \mathrm{~mm} /$ year. In years of high or average rainfall, and depending on the age of stabilized dunes, it is possible to find temporary ponds and streams. Nonetheless, and because of water instability, fish populations are not able to survive in this area (Fernández-Delgado et al., 2000). On the other hand, red-swamp crayfishes were introduced in SW Spain in 1974 (Gutiérrez-Yurrita et al., 1999) and at present they only appear in the northern part of the study area (Fig. 1).

Otter spraints were individually collected in paper envelops from latrines placed in the border of two ponds. The first one (pond A hereafter) is a semi-permanent pond of $5500 \mathrm{~m}^{2}$ that only dry up during extremely dry summers. In this place, we collected 106 spraints between 10 September and 24 November 1998, a year of above the average rainfall (around $700 \mathrm{l} / \mathrm{m}^{2}$ ). The closest water course was $1600 \mathrm{~m}$ far, and the next closest was $5 \mathrm{~km}$ away. Tracks found in the surroundings of the pond corresponded to at least two individuals, one of them much smaller than the other (presumably a mother with her cub). The second pond (pond B hereafter) is a typical temporary pond of $1600 \mathrm{~m}^{2}$, which dry up every summer. In this place abundant spraints could be found in 4 latrines from which we randomly took 30 samples. They were collected between June and September 2003, a year of average rainfall $\left(550 \mathrm{l} / \mathrm{m}^{2}\right)$. The closest water course to this pond was farther than $5 \mathrm{~km}$ away. An adult otter was sighted in this pond.

Samples were dried up in an oven for their preservation. All identifiable remains were considered, and both presence/absence of prey items, and their percent volume were recorded. These data were then summarized in form of frequency of occurrence (number of spraints where the prey item was found divided by the total number of spraints analized), and mean relative volume.

In pond A, crayfishes constituted $82.1 \%$ of otter diet in volume. Diving beetles and some few frogs were also consumed. In 


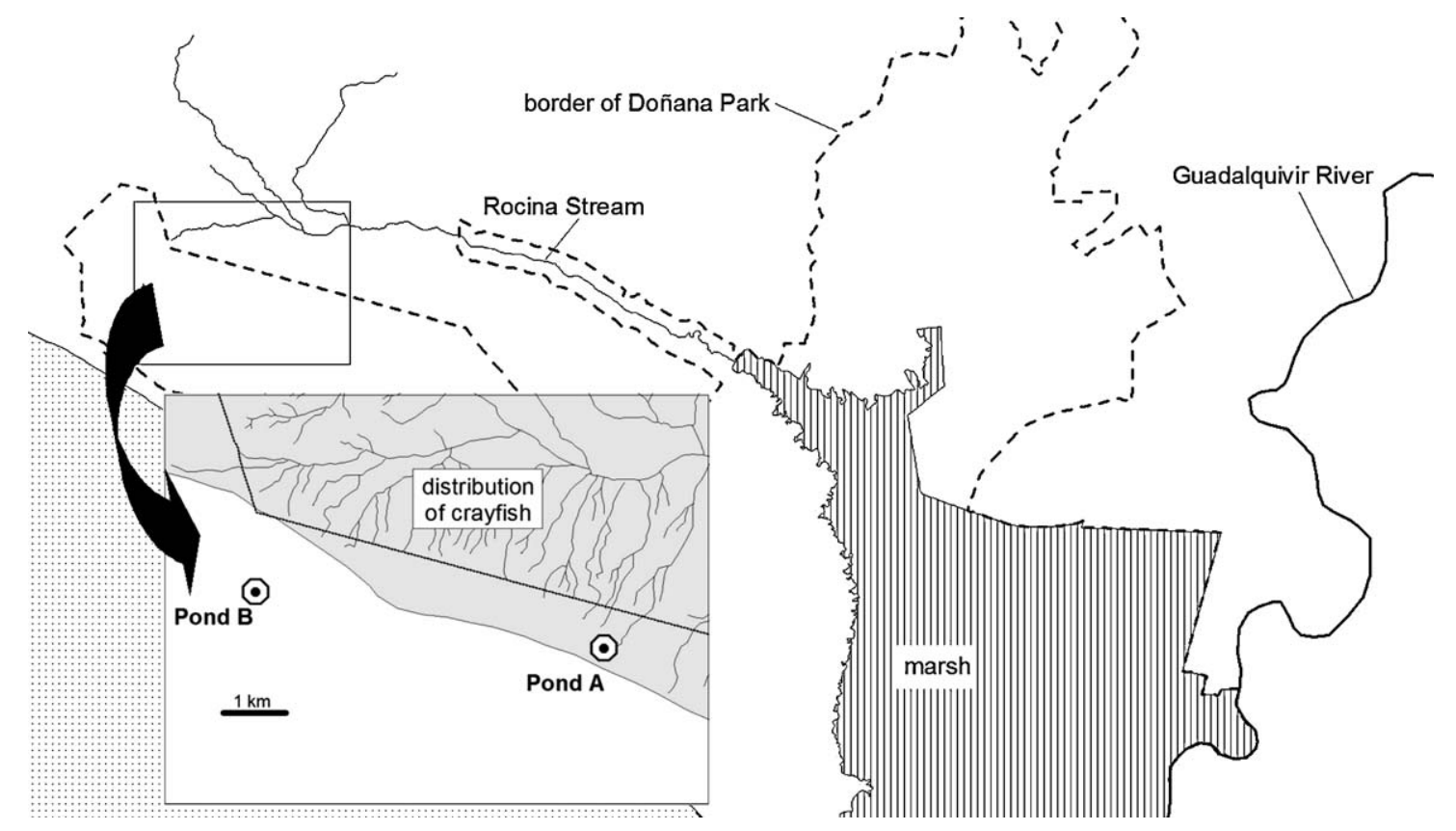

Fig. 1. Study area in the Park of Doñana. Presence of crayfishes is circumscribed to tributaries of the Rocina Stream detailed in the inset of the figure.

pond B diving beetles were virtually the only prey item with $97.3 \%$ of volume, although frog remains also appeared in some spraints (Table 1).

In Doñ ana, when crayfishes were present, otters fed mainly on them, even in places with fishes (Delibes and Adrián, 1987). Nevertheless, in studies conducted in 1981-1982 before the arrival of crayfishes to the area (Delibes et al., 2000), otters lived only in sites with fishes and the main otter's food was large Eels (Anguilla anguilla). Once depleted, otters were forced to feed on less profitable prey (small eels and mosquitofish, Gambusia affinis), which constitute the cue for leaving these ponds. Our results challenge this suggestion, showing that otters can also rely upon abundant or vulnerable prey such as crayfishes or diving beetles. This suggests that otters are able to temporally exploit marginal areas and feeding on other locally abundant prey (Lizana and Pérez Mellado, 1990; Weber 2008). Our findings are probably related to the generalized increase that otter populations have experienced in Spain (LópezMartín and Jiménez Pérez, 2008) and their high dispersal abilities (i.e. Barrientos et al., 2003). This may explain why otters currently live in small ponds and streams, constituting the extreme of the gradient of water instability described by Clavero et al. (2008), where otters do not prey upon fish but depend on crayfishes and diving beetles to survive. Nonetheless evidences of reproduction found in one of the ponds suggest that these marginal areas may become suitable places for breeding otters. Recently Ruiz-Olmo and Jimenez (2009) have shown that otters can also breed (even if less frequently) in zones of lower stability.

Table 1

Results of otter diet analysis. \% F = percentage of occurrence (number of spraints containing a prey/total spraints $\times 100$ ), $\% \mathrm{~V}=$ percentage of volume (estimated volume of each prey type/total estimated volume $\times 100$ ).

\begin{tabular}{|c|c|c|c|c|}
\hline & \multicolumn{2}{|c|}{ Pond A $(N=106)$} & \multicolumn{2}{|c|}{ Pond B $(\mathrm{N}=30)$} \\
\hline & $\% \mathrm{~F}$ & $\% \mathrm{~V}$ & $\% \mathrm{~F}$ & $\% \mathrm{~V}$ \\
\hline Procambarus clarkii & 106 (100\%) & $82.1 \%$ & 0 & 0 \\
\hline Dytiscidae & $69(65.1 \%)$ & $17.6 \%$ & 30 (100\%) & $97.3 \%$ \\
\hline Rana perezi & $3(2.8 \%)$ & $0.4 \%$ & $6(20 \%)$ & $2.7 \%$ \\
\hline
\end{tabular}

\section{Acknowledgements}

We thank M. Delibes, M. Clavero and C. Rodríguez for improving with their suggestions a previous draft of the manuscript and Gema Ruiz for helped with fieldwork.

\section{References}

Adrián, M.I., Delibes, M., Sunyer, C., 1990. Huelva. In: Delibes, M. (Ed.), La nutria (Lutra lutra) en Españ a. Colección Técnica, ICONA, Madrid, pp. 29-31.

Barrientos, R., Gil, T., Hernando, J., Iglesias, A., Jimenez, M.D., Navarro, E., 2003. Influencia de un embalse sobre la distribución y alimentación de la nutria (Lutra lutra L.) en el río Riaza (Segovia, Spain). Galemys 15 (no. especial), 81-90.

Barroso, J.L., Pineda, M.A., 1998. Andalucía. Huelva. In: Ruiz-Olmo, J., Delibes, M. (Eds.), La nutria en España ante el horizonte del año 2000. SECEM. Grupo Nutria, Barcelona-Sevilla-Málaga, pp. 47-49.

Beja, P.R., 1996. An analysis of otter Lutra lutra predation on introduced American crayfish Procambarus clarkii in Iberian streams. Journal of Applied Ecology 33, 1156-1170.

Carss, D.N., 1995. Foraging behavior and feeding ecology of the otter Lutra lutra: a selective review. Hystrix (Italian Journal of Mammals) 7, 179-194.

Clavero, M., Prenda, J., Delibes, M., 2003. Trophic diversity of the otter (Lutra lutra L.) in temperate and Mediterranean freshwater habitats. Journal of Biogeography 30, 761-769.

Clavero, M., Prenda, J., Blanco-Garrido, F., Delibes, M., 2008. Hydrological stability and otter trophic diversity: a scale-insensitive pattern? Canadian Journal of Zoology 86 (10), 1152-1158.

Delibes, M., Adrián, I., 1987. Effects of Crayfish introduction on Otter Lutra lutra Food in The Doñana National Park, SW Spain. Biological Conservation 42, 153-159.

Delibes, M., Ferreras, P., Blázquez, M.C., 2000. Why the Eurasian otter (Lutra lutra) leaves a pond? An observational test of some prediction on prey depletion. Revue d Ecologie-La Terre Vie 55, 57-65.

Fernández-Delgado, C., Drake, P., Arias, A.M., García, D., 2000. Peces de Doñana y su entorno. Serie Técnica. Ed. Organismo Autónomo Parques Nacionales, Madrid.

Gutiérrez-Yurrita, P.J., Martínez, J.M., Ilhéu, M., Bravo-Utrera, M.A., Bernardo, J.M., Montes, C., 1999. The status of crayfish populations in Spain and Portugal. In: Holdich, D.M., Vaninni, F., Gheardi, F. (Eds.) Crayfish in Europe as Alien Species: How to Make the Best of a Bad Situation? Universiteit van Amsterdam. Crustaceam Issues. Amsterdam, pp. 161-192.

Lizana, M., Pérez Mellado, V., 1990. Depredación por la nutria (Lutra lutra) del sapo de la Sierra de Gredos (Bufo bufo gredosicola). Doñana. Acta Vertebrata 17, 109-112.

López-Martín, J.M., Jiménez Pérez, J., 2008. La nutria en España. Veinte años de un mamífero amenazado. SECEM, Málaga, 493 pp.

Mason, C.F., Mcdonald, S.M., 1986. Otters, Ecology and Conservation. Cambridge universıty ress, Lambriage.

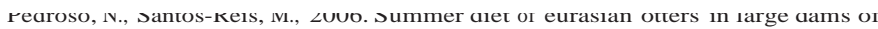
south Portugal. Hystrix (Italian Journal of Mammals) 17 (2), 117-128. 
Prigioni, C., Remonti, L., Balestrieri, A., Sgrosso, S., Priore, G., Mucci, N., Randi, E., 2006. Diet of the Eurasian otter (Lutra lutra) in relation to freshwater habitats and alien fish species in southern Italy. Ethology, Ecology \& Evolution 18, 307-320.

Remonti, L., Prigioni, C., Balestrieri, A., Sgrosso, S., Priore, G., 2008. Trophic flexibility of the otter (Lutralutra) in southern Italy. Mammalian Biology 73, 293-302.

Ruiz-Olmo, J., Jimenez, J., 2009. Diet diversity and breeding of top predators are determined by habitat stability and structure: a case study with the Eurasian otter (Lutra lutra L.). European Journal of Wildlife Research 55, 133-144.
Weber, A., 2008. Predation of invasive species chinese mitten crab (Eriocheir sinensis) by eurasian otter (Lutra lutra) in the Drömling nature reserve, Saxony-Anhalt, Germany. IUCN Otter Spec. Group Bull. 25 (2), 104-107.

Zazo, C., Dabrio, C.J., Borja, F., Goy, J.L., Lezine, A.M., Lario, J., Polo, M.D., Hoyos, M., Boersma, J.R., 1999. Pleistocene and Holocene aeolian facies along the Huelva coast (southern Spain): climatic and neotectonic implications. Geologie an Mijnbouw 77, 209-224. 